\title{
Work, the Brazilian Women, and the Teaching Profession: Some Notes
}

\author{
Tânia Antonelli Marcelino Brabo', Rosane Michelli de Castro², José Carlos Miguel² \\ ${ }^{1}$ Department of School Administration and Supervision, The Program of Postgraduate on Education in the \\ Faculty of Philosophy and Sciences, Universidade Estadual Paulista, Marília, Brazil \\ ${ }^{2}$ Department of Didactics, The Program of Postgraduate on Education in the Faculty of Philosophy and Sciences, \\ Universidade Estadual Paulista, Marília, Brazil \\ Email: tamb@terra.com.br, rosanemichelli@marilia.unesp.br, jocarmi@terra.com.br
}

Received 26 August 2015; accepted 16 October 2015; published 19 October 2015

Copyright (C) 2015 by authors and Scientific Research Publishing Inc.

This work is licensed under the Creative Commons Attribution International License (CC BY).

http://creativecommons.org/licenses/by/4.0/

(c) (i) Open Access

\begin{abstract}
In this article, we present some notes on three distinct themes, but whose understanding requires an interdisciplinary analysis considering presenting aspects that intertwine and feature dependent ways from each other. Thus, the introduction presents the world of work aspects in our society, seeking to situate the important participation of all its processes, including women, through training processes of the production of knowledge on education. Then, we present a reflection on the work of women, double work shift and the division of labor between the sexes. Finally, we discuss some historical aspects about the woman in the teacher profession in Brazil.
\end{abstract}

\section{Keywords}

\section{Education, Work, Women and Education}

\section{Introduction}

The process of building the Brazilian democracy still incipient brings with it a phenomenon that should be highlighted due to their social, political and economic: intensified women's participation in economic activity and gradually they increase their inclusion in decision-making, occupying important executive positions, with due emphasis to the election of Dilma Rousseff for two four-year terms as president. This scenario is unimaginable in the previous three decades.

Obviously, this is a phenomenon that occurs in many countries and whose pursuit of explanation, immediately reminds us of the economic expansion, with the acceleration of technological development, the industrialization and urbanization process and the struggles of member movements, including movements feminists who fight for 
equal rights. However, we note that this phenomenon even reverberates in periods of economic stagnation, with the consequent deterioration of job opportunities for jobs.

Despite the economic crises of the 1980s and 1990s, the expansion of indicators of women's participation rates, especially in the segment of women over 30 years, was the only factor responsible for the growth of the economically active population (EAP). It is also true that the restrictions in the labor market for the young and the effective participation of adult women in economic activity make the workforce assume higher age profile.

Paradoxically, the 1990s, marked by huge economic opening, with overwhelming inflow of foreign capital in the country, low investment, the privatization and outsourcing of the economy consolidated the trend of increasing incorporation of women as an indispensable workforce. This puts the new fact which further highlights the contradiction: in this decade the female unemployment is increased, which suggests that the expansion of jobs is not enough to absorb the entire growth of the economically active population of female nature.

In general, one can say that despite the economic turbulence that sweeps the world in recent decades, women's participation in the job market has grown significantly in the Brazilian context. The analysis of indicators of the Brazilian Institute of Geography and Statistics, IBGE, revealed that in 1960 the official rate of employment of women was $16.5 \%$. In 1992, this rate reaches $43.4 \%$, from $46.8 \%$ in 2009.

It should be noted in these analysis that female participation increased sharply between 1960 and 1990 and that thereafter there was a gradual growth, but oscillating sometimes with the indicators at between $42 \%$ and $50 \%$ between 1990 and the present day. For example, in 2012 the data indicate that 42.47\% participation of women in the economically active population should be noted that these small oscillations are due basically to the behavior of the Brazilian economy which is still relatively dependent and peripheral in the context of the internationalization of markets.

There is a marked tendency for women pass to occupy more and more space in the companies and the best places. It is a fact that women are qualified increasingly and occupy positions previously occupied mostly by men.

It appears, too, that women's participation in the labor market increases as they advance in years of schooling. Paradoxically, it is still significant level of illiteracy among women. Historically, the creation of the Brazilian family is patriarchal in nature, regime in which until recently was attributed the need to study for men, and women getting the training relegated to the background. In addition, it is worth remembering that.

"The solution of educational problems does not lie exclusively in school. History has shown that no country in the contemporary world has achieved high levels of literacy without their populations have won both substantial improvements in their living conditions and a more equitable distribution of income. The resulting confrontation of illiteracy in Brazil requires, on the one hand, a comprehensive policy that will lead the country to economic development with social justice, overcoming the current situation of extreme inequality of income distribution, goods and services; on the other hand requires a systematic educational policy and long-acting that prioritizes the universalization of primary education and respect regional specificities.” (Declaration of Literacy Brazilian Congress of Participants held in São Paulo, Brazil, in September 1990).

It is the movement for the emancipation of women, plus the taxes raised by increasing industrialization, with strong demands of social and economic needs, changing the profile of the Brazilian family, which makes this situation becomes in Brazil, with women gradually increasing its qualification via school and occupying massively jobs once occupied by men.

From our viewpoint, the issue involves a situation of multiple determinations. Leontiev (1978b: p 265) refers to the importance of productive activity in shaping the individual:

"[...] From the beginning of human history, the own men and their living conditions have left to modify and acquisitions of evolution to transmit from generation by generation, which is the necessary condition of continuous progress historic. It is necessary therefore that these acquisitions are showered. But as if-we have seenthey can't settle under the influence of biological inheritance? It was in an absolutely particular way, so that only appears with human society: that of external phenomena of material culture and intellectual. This particular form of fixation and transmission to future generations of the evolution of acquisitions owes its appearance to the fact that, unlike animals, men have a creative and productive activity. It is above all the case for fundamental human activity. Work (emphasis added)"

So is the work activity, considered as intentional activity of transformation of nature to answer a human necessity, which enables the objectification of the subject, the expression of his idea, his conception of his doing. But, the same time allowing the objectification of the subject, within the scope of activity and social relation- 
ships entailed to it that the idea, the conception and the human making are constituted.

In this way, the skills to use the tools, thought and knowledge to a new generation are formed by the cultural wealth ownership and cognitive activity produced by the preceding generations, through the communication process that happens in relations between the generations more old and younger. This finding is critical because the whole process of emancipation is based in the educational process, adult way to fight the yoke of the human species by the human species.

Nevertheless, the impact of changes in the production process via microelectronics is well known: to accentuate the social division and the technical division of labor, if purging - skilled workers; there is a process of trans-nationalization of capital; the labor market is becoming more selective; and, among other things, imposes the requirement for worker training that gives you a global vision, initiative, creativity, critical analysis, ability to transfer knowledge and cooperative relationship.

In instigating work on the influence of productive transformation in the capital structure, Braverman (1980) highlights two key factors: the rationalization of work organization and the constant application of technology and science in the production and economic activity. Indeed, the influence of microelectronics in production processes induced, since this time, the possibility of overcoming the paradigm of Fordism and brought out evidence of what might be called the phenomenon of Toyotism. For the limits of this study, import scientific management and technical-scientific revolution as two impacting factors for the transformation of competitive capitalism into monopoly capitalism. And the influence of microelectronics in managing the production process.

In the globalized world marked by competitiveness through internationalization of the economy, mass education came to constitute one of the most significant features of industrial societies. As the woman advances in schooling, qualify the debate on the emancipation and progress in the occupation of jobs.

Ciavatta and Rummert (2010: pp. 464-465, the authors' emphasis) also address this issue and consider that,

"We are therefore faced with a framework in which are supported the analyzes of Marx $(1979,1980)$, Gramsci (1978) and Kosik (1976) to evidence the fact that the entire production process, to bring about new configurations of processes work and social division, presents new demands regarding the necessary work. This perspective highlights the organic connection between education and work and allows us to understand the curriculum as a way of materialization of this joint. It can thus transcend the hegemonic interpretations that present relations between labor and education as a result of the phenomenal linear plan and the curriculum as mere expression of a intraescolar and/or pedagogical process, in the strict sense”.

Added to this the fact that in the global economy, education is necessary for the individual to be more productive and can consume more goods, no matter therefore the mere exclusion of persons, so that the situation of women's participation in economically active population gradually changes.

In this sense, civil society has a role very well defined in the fight for a school that effectively contributes to expand the scope of people to the social right of decent work policy that gradually progresses, especially favoring the inclusion of women in the labor market, but there are still important gaps that need to be considered. It is up to the Brazilian society organized the role of acting to ensure favorable conditions for study and training of professionals committed to the needs and popular aspirations, installing from these formation processes the production of knowledge on education and interfering in public policy in this area knowledge.

On the other hand, to move forward in building a more promising reality for the status of women is necessary to recognize the historical subjects that make up the educational activity, learners and educators, enabling policies to enable such stakeholders better understand the responsibility it holds. This move consolidates the certainty that it can't private the population of symbolic goods socially produced and are socialized in school practice. In this sense, we insist that all of Brazilian society has a role to play. The role of public education must be in order to direct and organize this discussion.

\section{The Insertion of Brazilian Women in the Workplace}

The value of women's work is a universal and historical problem, and the position of women varies from society to society, according to the prevailing political and economic relations. As Blay (1994), each nation has its own cultural ways, economic and political to implement this subordination.

Even in societies where the woman is in a more equal position in relation to man, as in American society, the organization of work after the Second World War, based on segmentation, influenced and limited employment opportunities for women and minority workers. Manipulating the productive forces made about women's work, 
defined not only the areas in which it allowed them to continue or start to act, but also deprived them of amount to administrative positions of greater influence, making them always subordinate to male elements where they worked. As Beauvoir (1970: p. 162), “[...] his condition approached the European women [...] who had legally guaranteed the religious and moral roles, but who held the most power in society, too, as in other societies, he was the man.” They also resorted to hand-cheap labor potential, both in industry and in trade.

In Brazil, because of the way it gave our culture, barriers to the female population have long been insurmountable. As Saffioti (1969), Blay (1994), Hirata (1998) and Bruschini (2000) analyze the female labor force can be largely employed in the formal labor market depending on the class society's needs: when it is necessary lower production costs, when you need to raise its rate of economic growth.

As proof of this, just at the Women's Decade, which began in 1970, there was a drop in the number of workers. As Blay (1994: p. 2) found in the state of São Paulo, between 1973 and 1977, the female rate was 25.48\% increased to $36.02 \%$, there was the absorption of more women in industries and even in administrative sector, however, the workers were all semi-skilled. At the same time, "also raised up the incorporation of children between 10 and 14 [...] But the increase in the female contingent was marked by lower wages of women in general [..]".

With regard to the education of women and of women's work in education, it is important to consider that when the school began to be organized in Brazil, female education has been linked to the role of women in society and to articulate vocational training to the labor market. Entry of women was to be difficult in the higher education, so that they amounted to university level only after 1930. In most cases, were driven by the government and families, to branches of education considered most suitable to women's professions. Saffioti (1969: p. 246) thus stands on the issue:

"The aspirations of upward mobility, largely responsible for the greater attention it deserves today by female education and the women's engagement in occupations outside the home, do not exceed, however, the need that class society has to keep its own balance to prioritize occupations male and female, in defense of chief position which men occupy in the family and in society. Thus, if the professional qualifications of women interfere in this occupational position, the stratification by gender intervenes, often negatively, whether the qualification of female labor force, both in the positioning of women in the occupational structure."

Even as Saffioti (1969), the company is leading the female population for certain branches of education less valued socially, as occurred relative to the feminization of teaching from preschool and elementary school. The government drove the woman to conduct courses as: Education, Literature, Geography and History, even if they were entitled to join other top courses. Also according to the author, even when amounted to a higher level course, we observed a greater concentration on areas where we can observe a process of social devaluation, as in the case of Pharmacy Course; in music conservatories, because the music was valued in girl's education; in the commercial education of a higher level and also in the professional technical education that would qualify the workforce to work in tertiary activities, highly valued by the lower social strata and the lower strata of the middle class population. Society in general, and families, in particular, took the decision as to in which sectors of the economy should be employed female workforce.

In recent decades there has been also that the formal education system directs both sexes for certain branches of education and the choices for such areas are given from the structural and ideological determinations. As exposes Blay (2002, p. 77) "The university courses taken in the third millennium entry are still corresponding to the sexual division of labor in household activities, applying in the areas of care, the teaching of family maintenance $[\ldots]$ ”

As Rosenberg and Pinto (1985) report, women make choices as a survival strategy against the contradictions of everyday life; it even explains the majority of students in training courses for the teaching profession, as well as the faculty predominantly female in preschools and elementary schools in the country, even in the face of professional devaluation. These choices will influence the endurance of sexual division of labor as Kergoat (2003) exposes. According to the author, the sexual division of labor is a form of division of labor resulting from the social relations of sex. This form is historically and adapted to each company by taking features to priority allocation of men to productive sphere and women's reproductive life. Thus, there is the choice of men, the functions of most social recovery and higher pay. This form of social division of labor has two organizing principles: the principle of separation (there are works of men and women work), and the principle of hierarchy (one man's job "worth" more than a woman's work).

Among other determinants of greater or lesser participation of women in the labor market, education is very 
important. It is believed that "education is a factor in determining the occupational status and economic situation not only of women but also of men; through it, can contribute to the reduction of social inequalities" (Gouveia, 1980: p. 4). In this sense, it is believed that the school can have a positive impact to the economic situation of women, it is observed that the lower classes and of low educational level employment opportunities are limited to occupations related to service delivery, mostly as maids, often without a formal and without the guarantee of other labor rights.

Conceives that it is the teaching which is the great power of women to change for his role as educator is historic and yet, because of the school's subordination to the government, the ruling classes and the very organization of work in the system school, women do not realize they are discriminated against. The school still plays the role of transmitting culture from the viewpoint of the dominant ideology, rather than creating new humanizing cultural standards. Geraldi (1996: p. 35) is positioned in this regard saying that the "professional degradation will unconsciously constituting a voluntary submission”.

Similarly the sexual organization of work of Brazilian society, a woman-teacher working hours is also tiring. Moreover, in most cases, it takes several days, the fact that domestic work continues to be performed primarily by her and other activities concerning the care in the family. His professional activity remains subordinate to the family and position subsidiary to the head of household. This is the reality for most of married teachers.

In the face of this vicious circle, difficult to break, women end up conceiving his salary as complementary. Although his work has great social value, end up not assimilate a professional identity. Not having time to read, take courses and to reflect on its role as a woman and educator, can't break away from the role of breeding discriminators models, reinforcing the androcentric view of the world, mostly either in teacher relations/student, direction/teacher, and in their pedagogical practice. Overall, we found that there was no social change in all aspects of society, legal standards coexist, allocating a social position to women the same as man, and actual patterns, featuring the permanence of the patriarchal society values that discriminate against women, as Blay (1994) found in the 1970s.

However, it is clear that with regard to teaching in Brazil, from its feminization process initiated in the imperial period, there is an achievement of women in this field, since, with the creation of the first faculties of Philosophy and Sciences, they managed to break through the barriers imposed on them with respect to their education, entering the courses of Higher Education. Currently, in terms of years of study, women outnumber men, however, this does not translate into equal pay, there is still a wage gap for women. So the next topic, we present some aspects of the feminization process of primary teaching in Brazil.

\section{Woman and Teaching in Brazil: Some Aspects}

All longing for modernization of the state of São Paulo through the diffusion of primary public education, reflected in the numerous reforms for which this level of education passed in the early twentieth century, gradually boosted demand from instructional population groups, markedly in São Paulo in an intense process of urbanization and industrialization of new and growing need for a skilled workforce with different levels of qualification and responsibility generator

In this context of socio-economic, public education was endowed with political and social relevance: the teaching profession in primary education, considered unworthy occupation, it came to be exalted in the speeches of our politicians and educators.

As Catani said (1989: p 118), the first Republican reformers praised the nobility of the teacher's mission and the ideals that should govern their conduct; They described their attributes and skills emphasizing the moral qualities necessary for the formation of adaptive individuals in a new conditional society by formal and legal requirements for an idealized capitalist order, existing, according to Costa (1983: p 36) "in central hegemonic countries and whose culture is nourished our intellectual elites.”

Despite the exaltation of rhetoric primary public teachers and their social function not result in an improvement of their economic situation, the São Paulo schools training primary teachers passed, year after year, receiving a growing number of students and especially students, showing the upwardly mobile aspirations of different social groups and, above all, participation of women in a professional branch of recognized social importance.

However, according to studies carried out by Pinto (1984, p. 111-114) especially during the 1900s and 1910 was severe unemployment frame and misery in Sao Paulo. The accelerated process of change in the economic 
structure in search of a new era of progress could not account for the misery situation of the population. The wide advertising undertaken by the coffee imigrantista policy to attract labor-cheap labor swelled the army of unemployed throughout the state of São Paulo, which was economically unable to accommodate the large contingent of the working class available for the production process. In other words, it occurred in the state capital a sudden population increase, disproportionate to their capacity to generate jobs, leading to the emergence of a climate of poverty and search for opportunities for social mobility and, ultimately, of survival.

In this context, school education has emerged as a privileged instrument for social mobility and the profession of public primary teaching embodied the hopes mobility of the various layers of the population inflamed by laudatory speeches about the role to be played by schoolteachers. It is very likely that the teaching profession the exaltation of speeches have come down to the people through these authorities, considering the great social prestige it enjoyed and, by virtue of which were heard by the entire local population, usually goer of school events such as closing celebrations of the school year, opening schools and civic celebrations, considered true social events.

Encouraged or not the laudatory tone of these discussions of public education authorities of the time, it is certain that the number of men and especially women in search of training schools for the exercise of this profession has increased considerably each year, especially when compared to number of students enrolled in official state gyms geared for entry in higher education.

The official speeches on the conditions of life and work, and salaries of teachers of primary public education by the various public education authorities have created a mixed picture on the primary teaching profession to put these professionals between two apparently contradictory situations: the professionals endowed with important social role and at the same time, the professionals who lived in a situation of dire financial straits. However, in times when the vast majority of workers in industrial centers, when they could stay in employment were subject to "starvation wages", and without any qualification, did not enjoy any social prestige, as stated Pinto (1994: p. 74), the laudatory speech on the primary teaching profession certainly gave the latter an attractive image, particularly in the eyes of workers and smallholders, many immigrant families and women who tried to be inserted in the wage labor market and win status and respectability within society.

As Sforni (1996: p. 16) said, just as Europe was afraid at the beginning of the twentieth century, social disorder caused by unemployed free workers, also in Brazil feared the effects arising with the changes in the work order that gave freedom to slaves and appealed mainly to the state of São Paulo, immigration and free those unhappy workers. Such concerns have triggered the process of extension of public services of primary education, linking it also with a project control and social order.

Drawing on these requirements, compared to which the Government of the State of São Paulo found itself, had surely as stated Sforni (1996: p. 83), the educational mission was associated with a process to be established for promoting self-government for each individual and should be carried out by candidates for the profession of primary teachers, holders of social virtues grounded in altruism, kindness, selflessness, solidarity, spirit of unity and patriotism. In short, the principles that placed as the ideal "public good" above the individual well.

The official speeches to the selection of individuals for the primary public school teachers relied on the argument that it was necessary to have the vocation needed to be schoolteacher, vocation which translated as innate abilities. The requirements for educational work which aimed at moral regeneration associated to the idea of selecting for the teaching profession in primary education bring those individuals who have built a sense of moral translated in a spirit of acceptance of socially sanctioned norms.

Believing himself the scientistic theories that said that the woman had the standard of behavior required for teaching, official power invested efforts for women's pattern for the profession of primary teaching. It translated into the picture about all the requirements for the exercise of the teaching profession associating it with the woman. Believing himself the scientist theories that said that the woman had the standard of behavior required for teaching, official power invested efforts for women's quota for the profession of primary teaching. It translated into the picture about all the requirements for the exercise of the teaching profession associating it with the woman.

In view of the discourse of requirements for the exercise of the teaching profession, expectations towards primary education, it is clear that public education authorities had clear that the operation of the school unit was not only guaranteed by law, but also by prescription customs officers to be mainly transmitted by teachers, supposedly the carriers of feelings and virtuous behaviors taken as the maternal characteristics that have been naturalized in women have become important prerequisites for the exercise of the teaching profession in primary public education. 
So even extolling the only maternal skills of women, the official discourse turned out to provide conditions for the feminization of primary teaching, a ball that was too expensive to men since, through it, you can exercise power and influence in decisions political and administrative.

\section{Final Considerations}

Finally, we can consider that the phenomenon in question is the result of a combination of economic, social, political and cultural factors, basically configured in the triad democratization, industrialization and education. But nothing is quiet in this process: the woman still has relatively lower earnings than men. There is still some prejudice by occupying the woman managerial posts and an educational problem which needs to be solved: illiteracy among adult women is even higher than among men, despite significant contingent of them seek inclusion in school, especially in the area of adult education.

It is true that we live in a time when the social circumstances, Brazilian political and cultural being profoundly altered. In this scenario, social actors previously invisible are organized in movements, now have voice, explaining their differences and bringing up their specific demands. By the same token, the development of the global market economy gradually incorporates new technologies and new forms of management, which imposes other requirements of school knowledge by workers. No longer just push buttons; there is the need to develop the decision-making capacity over the entire production process. This affects the entire labor process, broadly speaking, each employee becomes a manager.

Paradoxically, although create a significant progression demands and various kinds of needs in contemporary society lays unveils an uneven process of access to cultural goods produced. Indeed, illiteracy still stands out as the main factor of social exclusion, despite efforts to overcome them and affect the process of participation of Brazilian women, whether in the labor market, either in the decision-making process. Cruelly, in the midst of the social debt of illiteracy, denial of other fundamental rights: dignified survival, full employment, health, housing, restrictions on democratic participation, etc.

In the face of this situation, all the positions that end up being occupied by women in the Brazil, as well as what we present how the feminization of the Magisterium are, in fact, conquests and no concession made by the male audience.

\section{References}

Braverman, H. (1980). Trabalho e capital monopolista: A degradação do trabalho no século XX. Rio de Janeiro, Zahar. Beauvoir, S. (1970). O segundo sexo. 1. fatos e mitos (4th ed.). São Paulo: Difusão Européia do Livro.

Blay, E. A., (2002). Gênero na Universidade. In: Educação em Revista (pp. 73-78). Universidade Estadual Paulista, Faculdade de Filosofia e Ciências. Marília: UNESP, Marília Publicações.

Blay, E. A. (1994). Mulheres e Movimentos Sociais. In: São Paulo em Perspectiva. Revista da Fundação SEADE, 8, 45-47.

Bruschini, C. (2000). Gênero e trabalho no Brasil: Novas conquistas ou persistência da discriminação. In Rocha, M. I. B. da (Org.), Trabalho e Gênero: Mudanças, permanências e desafios (pp. 13-58). Campinas: ABEP, NEPO/UNICAMP e CEDEPLAR/ UFMG/São Paulo, Editora 34.

Catani, D. (1989). Educadores à meia luz. São Paulo. Tese (Doutorado em educação)—Faculdade de Educação—FE/USP.

Ciavatta, M., \& Rummert, S. M. (2010). As implicações políticas e pedagógicas do currículo na educação de jovens e adultos integrada à formação profissional. Educação e Sociedade, 31, 461-480.

http://dx.doi.org/10.1590/S0101-73302010000200009

Costa, A. M. C. I. (1983). A escola na República Velha-Expansão do ensino Primário em São Paulo. São Paulo, BR: EDEC.

Hirata, H. (1998). Reestruturação produtiva, trabalho e relações de gênero. In Revista Latinoamericana de Estudos do trabalho: Gênero, Tecnologia e Trabalho (pp. 5-27). São Paulo; Rio de Janeiro: ALAST, ano 4, n. 7.

Leontiev, A. N. (1978b). O Desenvolvimento do Psiquismo. Lisboa: Livros Horizonte.

Pinto, M. I. M. B. (1994). Cotidiano e sobrevivência: A vida do trabalhador pobre na cidade de São Paulo, 1890-1914. São Paulo: EDUSP.

Saffioti, H. I. B., \& Muños Vargas, M. (1969). A mulher na sociedade de classes: Mito e realidade. São Paulo: Quatro Artes.

Sforni, M. S. F. (1996). A feminização do corpo docente na democratização do ensino no século XIX. Maringá-PR-BR, Dissertação (Mestrado)—Universidade Estadual de Maringá. 